MALACOLOGIA, 2013, 56(1-2): XXX-YYY

\title{
PHENOTYPIC DIFFERENTIATION OF ECOLOGICALLY SIGNIFICANT BRACHIDONTES SPECIES CO-OCCURRING IN INTERTIDAL MUSSEL BEDS FROM THE SOUTHWESTERN ATLANTIC
}

\author{
Mariana L. Adami1*, Guido Pastorino2 \& J. M. (Lobo) Orensanz³
}

\begin{abstract}
Intertidal communities from rocky shores of the southwestern Atlantic are dominated by two small-sized mussels of the genus Brachidontes, $B$. rodriguezii (d'Orbigny, 1846) and $B$. purpuratus (Lamarck, 1819). Their generic placement, separation of specimens based on external conchological characters and geographic distribution are problematic. We conducted a comparative study based on extensive collections and observations at 14 sites along the coasts of the southwestern Atlantic, complemented by the study of materials from museum collections. Well-preserved specimens of the two species are distinguishable on the basis of shell characters, some of them previously ignored, over their combined latitudinal range.
\end{abstract}

Key words: Brachidontes, mussels, Mytilidae, southwestern Atlantic, rocky intertidal.

\section{INTRODUCTION}

Mid-intertidal communities from non-estuarine rocky shores of the southwestern Atlantic are dominated by densely packed populations of two small mussels belonging to the genus Brachidontes Swainson, 1840, namely B. rodriguezii (d'Orbigny, 1846) and B. purpuratus (Lamarck, 1819). Those mussel beds constitute the most conspicuous component among the intertidal molluscan-dominated assemblages in the region. The two species are ecologically significant ecosystem engineers, dominating the physiognomy and structure of mid-intertidal rocky shore communities (Adami et al., 2004) and increasing biodiversity through facilitation (Silliman et al., 2011).

The range of geographic distribution of $B$. rodriguezii is restricted to the warm-temperate Argentine Biogeographic Province (Balech \& Ehrlich, 2008), whereas B. purpuratus occurs in the Magellanic Biogeographic Province (coldtemperate) and extends northwards along the southeastern Pacific to northern Peru (Coan \& Valentich-Scott, 2012). Reported ranges overlap in northern Argentine Patagonia between approximately $41^{\circ} \mathrm{S}$ and $43^{\circ} \mathrm{S}$.

The distinctness and phenotypic differentiation of these two ecologically significant species is still a matter of debate and much confusion. Several authors have considered them to be synonymous (e.g., Aguirre et al., 2006), and even their generic placement remains debatable. They are often misidentified in ecological and palaeobiogeographic studies (e.g., Aguirre et al., 2006; Cuevas et al., 2006; Torres \& Caille, 2009), and the boundaries of their distributions (Fig. 1) are not well resolved. This is due in part to them being phenotypically similar, which complicates identification particularly where their ranges overlap (Fig. 1). Also, mytilids are noted for their high phenotypic plasticity (Seed, 1968).

Here we describe both species on the basis of conchological characters. Shell characters indicated as diagnostic by previous authors, as well as features not considered before, were evaluated for consistency. In addition, we discuss their distributional range based on the literature, a survey of 14 sites along the Argentine coasts of the southwestern Atlantic, and examination of extensive museum collections, including existing type material.

\section{MATERIAL AND METHODS}

The study region extends over temperate and cold sectors of the southwestern Atlantic

1Museo de La Plata, Paseo del Bosque s/n, 1900 La Plata, Argentina.

2Museo Argentino de Ciencias Naturales "Bernardino Rivadavia", Av. Ángel Gallardo 470, C1405GJR Ciudad Autónoma de Buenos Aires, Argentina.

3Centro Nacional Patagónico (CENPAT - CONICET), Blvd. Brown 2915 (U9120ACD), Puerto Madryn, Chubut, Argentina.

${ }^{*}$ Corresponding author: madami@fcnym.unlp.edu.ar 


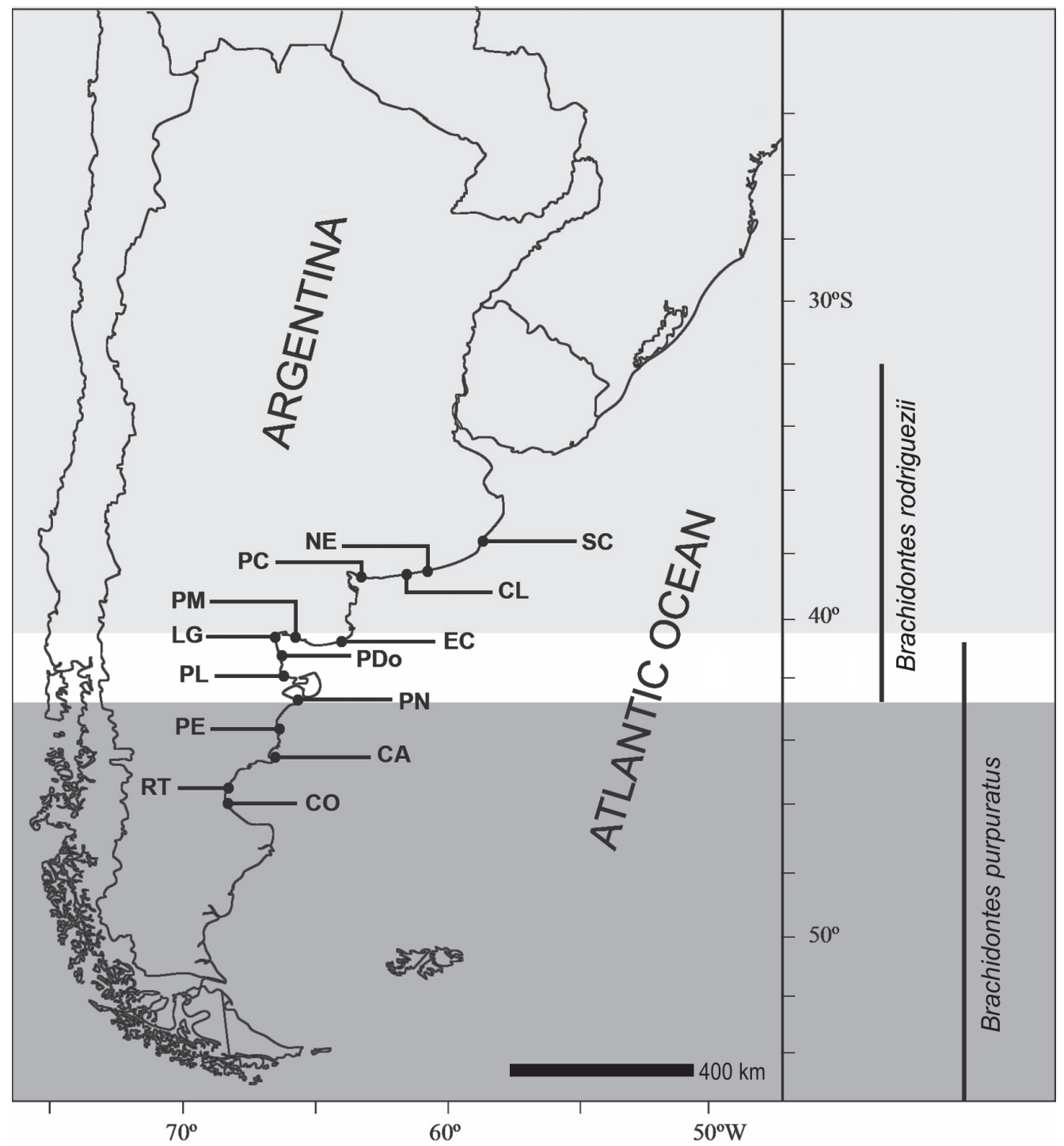

FIG. 1. Study region with indication of sampling survey sites, and latitudinal range of distribution of intertidal Brachidontes species within the region of interest. Abbreviations: SC: Santa Clara del Mar, NE: Necochea, CL: Claromecó, PC: Pehuencó, EC: El Cóndor, PM: Punta Mejillón, LG: Las Grutas, PDo: Playas Doradas, PL: Puerto Lobos, PN: Punta Ninfas, PE: Playa Escondida, CA: Camarones, RT: Rada Tilly, and CO: Caleta Olivia; Unshaded: Transition zone, light shading: Argentine biogeographic province, dark shading: Magellanic biogeographic province.

along the Argentine littoral (Fig. 1), known as Argentine and Magellanic provinces. The transition of both provinces for intertidal and nearshore habitats occurs in the gulfs San Matías, San José and Nuevo and the Valdés Peninsula (between $41^{\circ} \mathrm{S}$ and $43^{\circ} \mathrm{S}$; Fig. 1).
Specimens from the mid-intertidal rocky zone were sampled at selected locations along the Argentine coast. Availability of candidate sites is limited by accessibility, particularly along stretches of the Patagonian shoreline. The survey included 14 sites over approximately 
nine degrees of latitude from $37^{\circ} \mathrm{S}$ to $46^{\circ} \mathrm{S}$. All samples were collected between 2004 and 2008. Voucher materials from all locations included in this study are housed at the Invertebrate Collection of the Museo Argentino de Ciencias Naturales "Bernardino Rivadavia" (MACN) under the numbers MACN-In 3761634. All Brachidontes specimens deposited in the collections of the MACN and Museo de La Plata (MLP) were also studied. In addition the lectotype of Mytilus rodriguezii d'Orbigny, 1846, designated by Aguirre (1994) and deposited at the Natural History Museum, London (NHMUK 1854.12.4.809/1), was re-examined and is here illustrated (Figs. 15-17). As was pointed out by Soot-Ryen (1955: 45), the type material of Modiola purpurata is missing. Y. Finet, and M. Huber from Geneve (pers. comm)confirmed that it is not at Museum d'Histoire Naturelle, Geneva, where most of the Lamarck's material is housed.

\section{RESULTS}

Family MYTILIDAE Rafinesque, 1815 Genus Brachidontes Swainson, 1840

Type species: Modiola sulcata Lamarck, 1819 (by monotypy)

Brachidontes rodriguezii (d'Orbigny, 1846) Figs. 2-6

Mytilus rodriguezii d'Orbigny: 1846: 646; 1847 : pl. 85, figs. 9-11.

Brachyodontes rodriguezi (d'Orb.): Castellanos, 1957: 8, pl. 2, fig. 7, pl. 4, fig. 8.

Brachydontes rodriguezi (d'Orb.): Castellanos, 1970: 211, pl. 17, figs. 5, 6.

Brachidontes rodriguezi (d'Orbigny, 1846): Rios, 1994: 236, pl. 82, fig. 1164; Rios, 2009: 483, fig. 1357; Aguirre, 1994: 355, pl. 1, fig. 12a-d.

Brachidontes rodriguezii (d'Orbigny, 1846): Aguirre et al., 2006: 101, figs. 1, 5.

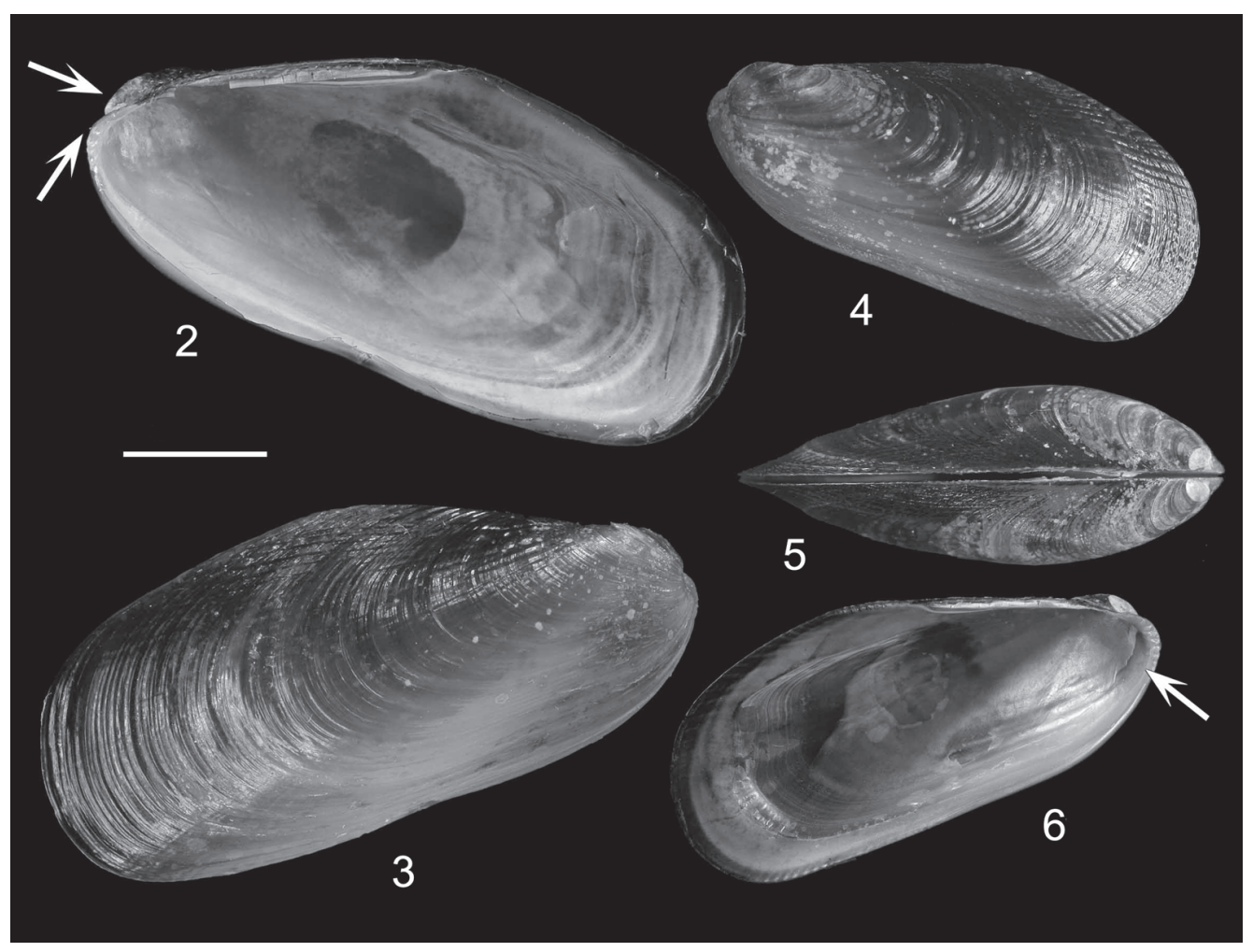

FIGS. 2-6. Brachidontes rodriguezii (d'Orbigny, 1846). FIGS. 2, 3: Claromecó, Buenos Aires Province, Argentina (MACN-In 37558); FIG. 2: Internal view of a right valve, arrows point to subterminal umbo and shell margin; FIG. 3: External view; FIGS. 4-6: Necochea, Buenos Aires Province, Argentina (MACN-In 37559); FIG. 4: External view of the left valve; FIG. 5: Dorsal view of articulated valves; FIG. 6: Internal view of the valve shown in Fig. 4; arrow points to the anterior adductor muscle scar. Scale bar $=5 \mathrm{~mm}$. 
Description: Shell mytiliform, thin, small to medium sized, approximately $40 \mathrm{~mm}$ length; umbones subterminal, rounded; marginal denticles posterior to ligament; hinge with 5-6 very small denticles. External ornamentation of radial, regular, very thin ribs, usually bifurcated, sometimes faint on the lower half; irregular growth lines covering the shell. Periostracum usually clear brownish on lower half of shell, and dark on the upper half Interior dark reddish, iridescent.

Material Examined: (spm.: complete specimens, otherwise specified)

Uruguay: $34^{\circ} 02^{\prime} 38^{\prime \prime} \mathrm{S}, 53^{\circ} 32^{\prime} 10^{\prime \prime} \mathrm{W}$, Punta del Diablo (MACN-In 37614), 20 spm.; La Coronilla (MLP 50023), 14 spm.; La Paloma, Rocha (MLP 4518-1), 3 valves; 3440'03"S, 5409'52"W, La Paloma (MACN-In 37615), $9 \mathrm{spm}$.

Argentina: Buenos Aires Province: Punta Canteras (MLP 7130), 100 spm.; Camet Norte (MLP 7139), 100 spm.; Miramar (MLP 7883), 1 spm.; Miramar (MLP 2323), 23 valves; $37^{\circ} 50^{\prime} 12$ "S, $57^{\circ} 29^{\prime} 46^{\prime \prime} \mathrm{W}$, Santa Clara del Mar (MACN-In 37616) 20 spm.; Mar del Plata (MLP 50037), 9 valves; Quequén (MLP 7132), 200 spm.; Necochea (MLP 2198), 2 valves; 38³7'20"S; 5849'30”W, Necochea (MACN-In 37617) 20 spm.; Claromecó (MLP 7131), 200 spm.; 3851'37"S, 6003'28”'W, Claromecó (MACN-In 37618) 20 spm.; Monte Hermoso (MLP 3615), 4

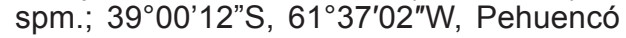
(MACN-In 37619), 20 spm.; Bahia Blanca (MLP 2692), 4 valves; Bahia Blanca (MLP 2855), 7 spm.; Bahía San Blas (MLP 4917-1), 10 valves; Río Negro Province: mouth of Río Colorado (MLP 1365), 7 valves; mouth of the Río Negro (MLP 50074), 1 spm.; 4050’2"S, $65^{\circ} 05^{\prime} 07^{\prime \prime} \mathrm{W}$, Las Grutas (MACN-In 37620), 20 spm.; 41 ${ }^{\circ} 03^{\prime} 28^{\prime \prime S}, 62^{\circ} 14^{\prime} 56^{\prime \prime} \mathrm{W}$, Balneario El Cóndor (MACN-In 37622) 20 spm.; Bahía Creek (MLP 4336-1), 132 spm.; 41 01'51'S, 6408'34"W, Punta Mejillón (MACN-In 37623), 20 spm.; 4137'41"S, 6502'08”W, Playas Doradas (MACN-In 37625), 15 spm. Chubut Province: Punta Cantor, Península de Valdés (MLP 4133-2), 5 spm.; Playa Larralde, Golfo San José, Península Valdés,(MLP 7141-2), 18 spm.; Península Valdés (MLP 4316-3), 1 spm. Golfo San José, off Isla de Los Pájaros (MLP 4911-1), 5 spm.; Puerto Pirámides (MLP 5169), 2 valves; Golfo Nuevo (MLP 2859), 1 spm.;
Punta Cuevas, Puerto Madryn (MLP 13141), 9 spm.; Golfo Nuevo (MLP, 3720-1), 25 spm.; Golfo Nuevo (MLP, 2836-2), 12 spm.; Puerto Madryn (MLP 2399), 4 valves; 4258'02"S, $64^{\circ} 19^{\prime} 01^{\prime \prime} W$, Punta Ninfas (MACN-In 37628), $12 \mathrm{spm}$.

Distribution: From Rio Grande do Sul, Brazil (according to Rios, 2009), to Punta Ninfas, Chubut Province, Argentina (42 ${ }^{\circ} 58^{\prime} S$ ). Cue-

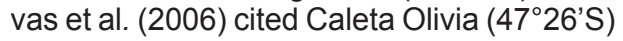
as the southernmost locality, however we failed to find it in localities south of Punta Ninfas (4258'02"S). Torres \& Caille (2009) reported only $B$. rodriguezii for Puerto Madryn. We revisited their study sites and observed specimens of both species, $B$. rodriguezii and $B$. purpuratus, living together in the same beds.

Remarks: Aguirre (1994) designated as lectotype the specimen housed at NHMUK under the number 1854.12.4.809/1, which is illustrated here in Figures 15-17. This species has been dated as 1842. However, d'Orbigny's plate 85, while in a livraison with a cover date of 1842, did not appear until May 15,1847 . The species therefore dates from its appearance in d'Orbigny's 1846 text $(\mathrm{N}$. Evenhuis, in preparation).

\section{Brachidontes purpuratus (Lamarck, 1819)} Figs. 7-14

Modiola purpurata Lamarck, 1819: 113.

Brachidontes purpuratus (Lamarck) 1819: SootRyen, 1955: 45, pl. 4, fig.18, text fig. 30.

Brachyodontes purpuratus (Lamk): Castellanos, 1957: 8, pl. 2, fig. 7, pl. 4, fig. 8.

Perumytilus purpuratus (Lamarck, 1819): Olsson, 1961: 116. pl. 12, fig. 1, pl. 14, figs. 1 , 1b; Osorio, 2002: 122, fig.; Coan \& Valentich Scott, 2012: 119, pl. 37, fig.

Brachidontes purpuratus (Lamarck 1819): Huber, 2010: 117, fig.

Description: Shell small to medium sized, up to approximately $50 \mathrm{~mm}$ maximum length, subtriangular, ovate, thick, very variable; umbones terminal; sculpture of coarsely wrinkled radial, usually bifurcated, ribs. Hinge with several subequal denticles. Anterior adductor muscle scar thickened, raised, usually hyaline. Margin crenulated. Periostracum dark blue. 


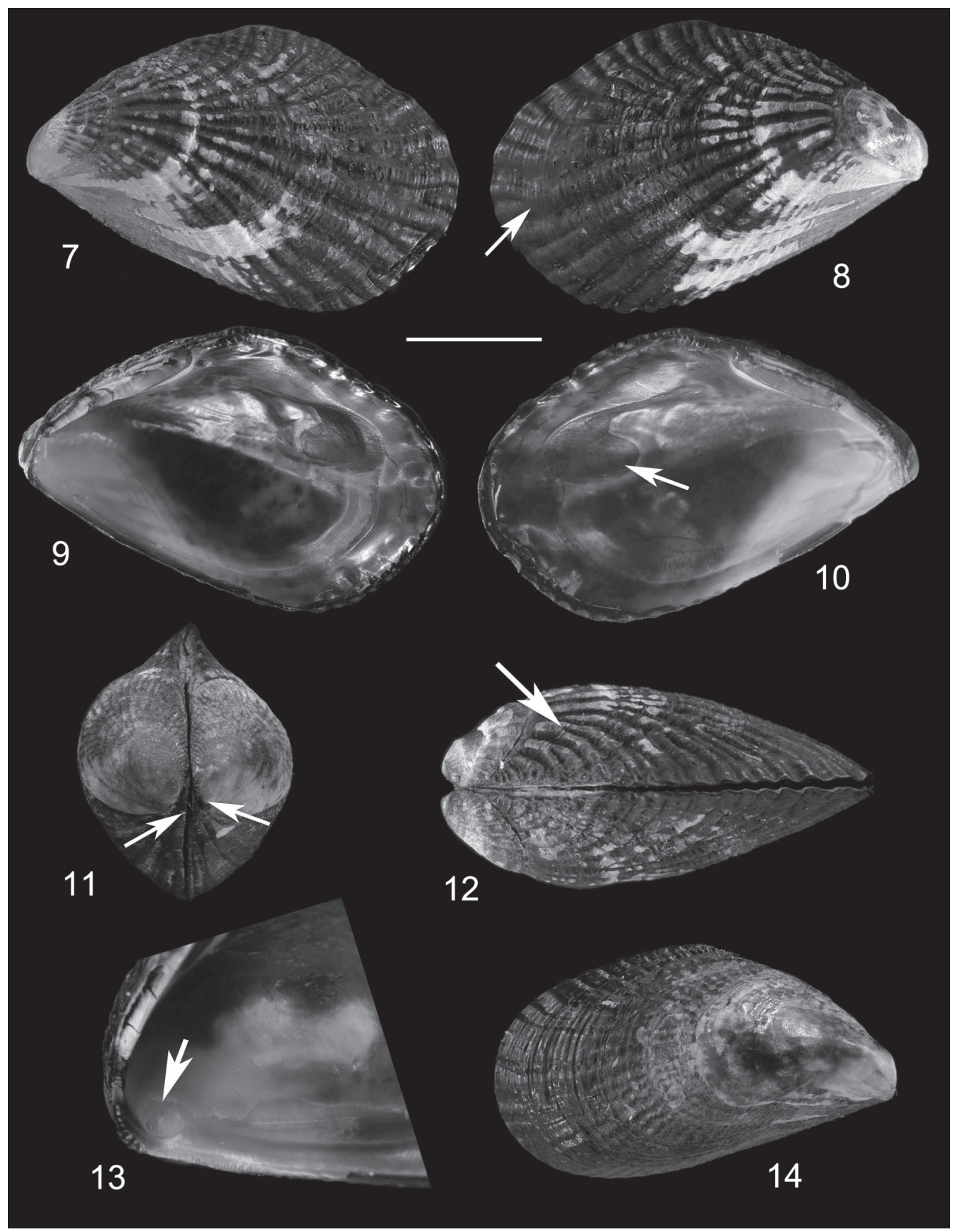

FIGS. 7-14. Brachidontes purpuratus (Lamarck, 1819). FIGS. 7-13: Camarones, Chubut Province, Argentina (MACN-In 37560); FIGS. 7, 9: External and internal view of a right valve; FIGS. 8, 10: External and internal view of a left valve, arrow points to the bifurcate rib and the posterior adductor muscle scar; FIG. 11: Umbonal view, arrow points to the end of the umbo (right) and the shell (left); FIG. 12: Dorsal view of the same specimen, arrow points to a bifurcate rib; FIG. 13: Internal detail of the hinge area of a right valve; arrow points to the anterior adductor muscle scar; FIG. 14: Punta Ninfas, Chubut Province, Argentina (MACN-In 37561 ), right valve of a specimen showing intermediate characters. Scale bar for all specimens $=5 \mathrm{~mm}$. 


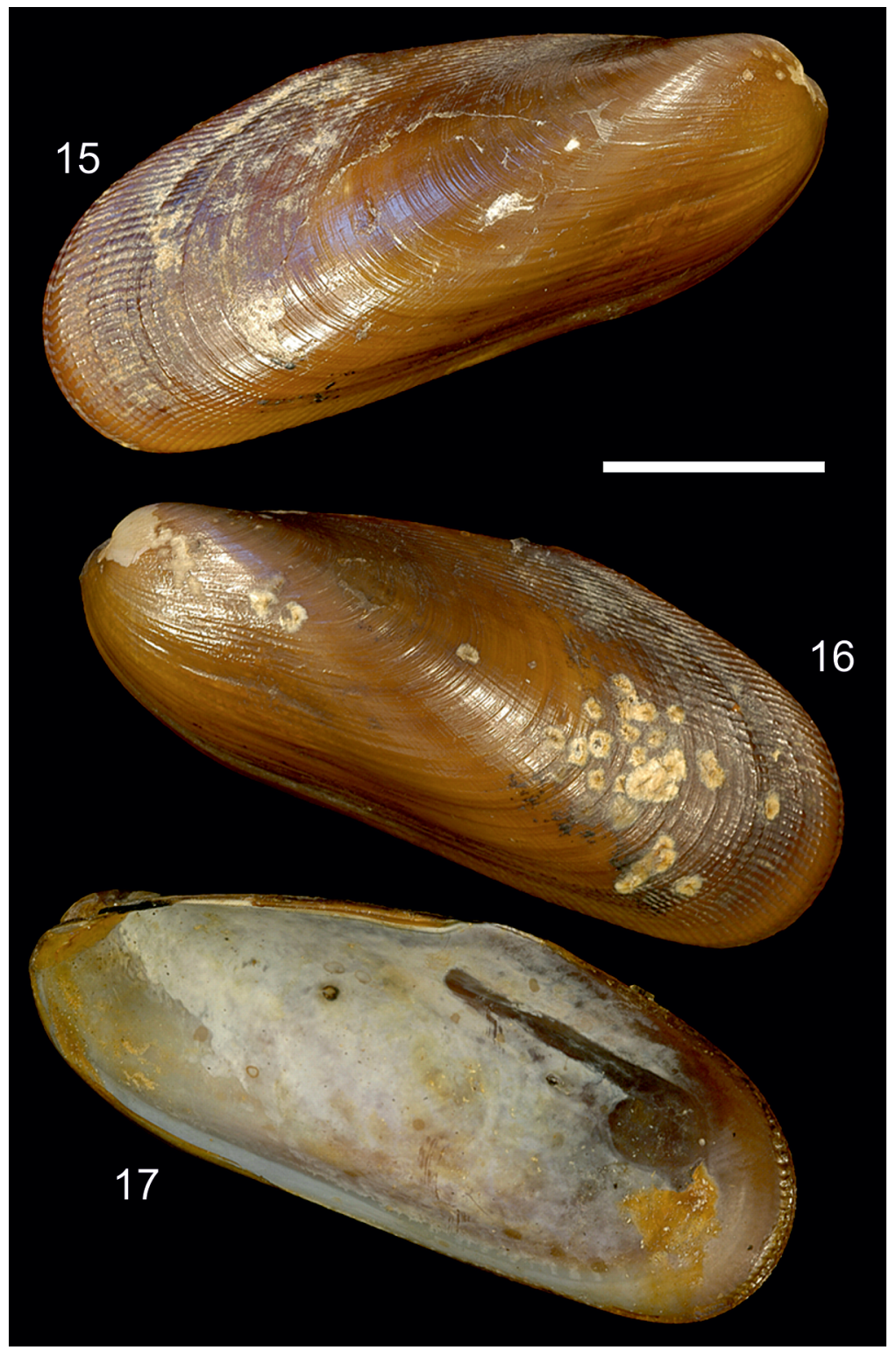

FIGS. 15-17. Lectotype of Mytilus rodriguezii d'Orbigny, 1846, NHMUK 1854.12.4.809/1; FIG. 15: External view of right valve; FIG. 16: External view of left valve; FIG. 17: Internal view of right valve. Scale bar for all specimens $=1 \mathrm{~cm}$.

Material Examined:

Argentina: Río Negro Province: $40^{\circ} 50^{\prime} 02$ "S, $62^{\circ} 50^{\prime} 07^{\prime \prime}$, Las Grutas (MACN-In 37621), 8 spm.; 4100'51"S, 6411'34"W, Punta Mejillón (MACN-In 37624), 13 spm.; 4136'41"S, $65^{\circ} 01^{\prime} 08^{\prime \prime} \mathrm{W}$, Playas Doradas (MACN-In
37626), 20 spm. Chubut Province: $41^{\circ} 59^{\prime} 10^{\prime \prime S}$ $65^{\circ} 03^{\prime} 57$ "W, Puerto Lobos (MACN-In 37627), 20 spm.; Golfo San Matías, Península Valdés (MLP 4316-1), 36 spm.; Punta Cantor, Península Valdés (MLP 4133-1), 50 spm.; Puerto Pirámides (MLP 7406-1), 50 spm.; 
TABLE 1. Comparison of morpological features of Brachidontes rodriguezii and $B$. purpuratus.

\begin{tabular}{lll}
\hline \multicolumn{1}{c}{ Character } & \multicolumn{1}{c}{ B. rodriguezii } & \multicolumn{1}{c}{ B. purpuratus } \\
\hline Valves & elongate (Figs. 2-6) & globular (Figs. 7-12) \\
Umbo & subterminal (Fig. 2) & terminal (Fig. 11) \\
Shell ribs & thin, smooth (Figs. 3, 5) & coarse (Figs. 7, 8, 12) \\
Rib pattern & parallel (Figs. 3, 4) & bifurcated (Figs. 7, 8, 12) \\
Adductor muscle scar & depressed, opaque (Fig. 6) & raised, hyaline (Fig. 13) \\
\hline
\end{tabular}

Playa Larralde, Golfo San José, Península Valdés (MLP 7141-1), 20 spm.; Golfo San José, off Isla de Los Pájaros (MLP 4911-2), 1 spm.; Golfo Nuevo (MLP 3720-3), 12 spm.; Punta Cuevas, Puerto Madryn, (MLP 13140), 9 spm.; 42 $58^{\prime} 02^{\prime \prime}$ S, 64 $19^{\circ} 01^{\prime \prime W}$, Punta Ninfas (MACN-In 37629), 20 spm.; Punta Marques (MLP 1152), 35 valves; 4343'21'S, $65^{\circ} 20^{\prime} 49^{\prime \prime} \mathrm{W}$, Playa Escondida (MACN-In 37630), 20 spm.; 445' $34^{\prime \prime S}, 65^{\circ} 33^{\prime} 20^{\prime \prime} W$, Camarones (MACN-In 37631), 13 spm.; 4505'52"S, 66³0'26"W, Bahía Bustamante (MACN-In 37632), 20 spm.; 4556'53"S, $67^{\circ} 33^{\prime} 12$ "W, Rada Tilly (MACN-In 37633), 19 spm.; Santa Cruz Province: Santa Cruz (MLP 2867), 5 valves; Comodoro Rivadavia (MLP 1711), 1 spm.; Comodoro Rivadavia (MLP 1704), 4 valves; Comodoro Rivadavia (MLP 5709), 20 spm.; 46²0'06"S, 67³4'14”W, Caleta Olivia (MACN-In 37634), 20 spm.; 4744'36"S, 6559'34"W, Puerto Deseado (MACN-In 37635), 20 spm.; Puerto Deseado (MLP 7884), 7 spm.; Puerto Deseado (MLP 3881), 6 spm.; Puerto Deseado (MLP 50028), 4 spm.; Puerto Deseado (MLP 4772-1), 2 spm.; Bahía del Fondo (MLP 1934), 23 spm.; Punta Piedra, Bahía San Julián (MLP 1708-1), 5 valves; 49¹4'50"S, 6740'12"W, Bahía San Julián (MACN-In 37636), 20 spm.; Bahía del Fondo (MLP 50021), 50 spm.; Bahía San Julián (MLP 50022-1), 22 spm.; B. Crosley, Isla de los Estados (MLP 50024-1), 15 spm.; Punta Peñas, San Julián (MLP 50025), 3 valves; Tierra del Fuego Province: Puerto Parry, Isla de los Estados (MLP 7384), 3 spm.; Isla Año Nuevo (MLP 4361-3), 1 spm.; Tierra del Fuego (MLP 1720) 3 valves; Tierra del Fuego (MLP 1721), 7 valves; Puerto Parry, Isla de los Estados (MLP 7384), 3 spm.

Chile: Puerto Hundido (MLP 1723), 14 spm.; Punta Arenas (MLP 2353), 1 spm.; Puerto Montt (MLP 3680), 1 spm.
Distribution: The northernmost site where we recorded the presence of $B$. purpuratus is Punta Mejillón ( $\left.41^{\circ} \mathrm{S}\right)$, northern coast of Golfo San Matías on the Atlantic Ocean. According to Coan \& Valentich-Scott (2012: 119), this species occurs in the Pacific from Estero Zarumilla, Tumbes, Peru, to the Estrecho de Magallanes, Chile.

\section{General Remarks}

Valves of adult individuals are elongate in $B$. rodriguezii (Figs. 2-6), globular in B. purpuratus (Figs. 7-12). The position of the umbo is subterminal in B. rodriguezii (Fig. 2), but terminal in B. purpuratus (Fig. 11). Shell radial ribs are fine and smooth, closely spaced, with divarications not visible to the naked eye in $B$. rodriguezii (Figs. 3, 5), and coarse and divaricating, particularly on the anterodorsal and posterior margins, in B. purpuratus (Figs. 7, 8, 12). The scar of the anterior adductor muscle is depressed and opaque in $B$. rodriguezii, whereas it is raised and hyaline in $B$. purpuratus (Fig. 13). The confidence of identification increases with size, but can also deteriorate with shell wear in large individuals. In addition, some adult specimens (e.g., Fig. 14) are difficult to classify when only one character (usually the external ornamentation) is considered. Characters are comparatively summarized in Table 1.

\section{DISCUSSION}

We identified a series of characters that allow the unequivocal separation of the two species. Aguirre et al. (2006) used 2-D geometric morphometric techniques in an attempt to objectively separate three species of the genus Brachidontes [B. rodriguezii, B. purpuratus and $B$. darwinianus (d'Orbigny, 1846)], based 
on planar projections of shell outlines. Brachidontes darwinianus was originally described from three locations: Rio de Janeiro (22 $56^{\prime}$ 'S, Brazil), Maldonado (345' $\mathrm{S}$, Uruguay) and Ross Bay ( $41^{\circ} 09^{\prime}$ S, Argentina). However, the record from Ross Bay probably corresponds to juvenile B. rodriguezii. Aguirre et al. (2006) could not find consistent differences and concluded that $B$. darwinianus and $B$. rodriguezii might be junior synonyms of $B$. purpuratus. Their pictorial illustration of phenotypic variation (Aguirre et al., 2006: fig. 4) is, however, difficult to interpret. Besides, none of the specimens illustrated resembles the type specimens of $B$. rodriguezii (Figs. 15-17). Some shells classified as $B$. rodriguezii by Aguirre et al. (2006) show diagnostic characters matching B. purpuratus (e.g., obviously bifurcate ribs). Their results, in our opinion, must be taken cautiously. Brachidontes purpuratus is the type species of the genus Perumytilus Olsson, 1961. According to Cox et al. (1969), the most comprehensive systematic compendium of bivalve genera, mussels belonging to Brachidontes Swainson, 1840, are defined as having "mytiliform shells with subterminal umbones, and radial sculpture on the ventral part simple or regularly bifurcating". The genus Perumytilus (type species Mytilus purpuratus Lamarck, 1819, by original designation), however, was not mentioned by Cox et al. (1969). The genus is monotypic; the range of the single species mentioned by Olsson (1961) is Gulf of Guayaquil, Ecuador, to Chile. However, SootRyen (1955) indicated that the range of this species is from the Straits of Magellan north in the Atlantic to Santa Cruz, Argentina. While the monotypic genus Perumytilus has been accepted by some authors in the taxonomic and ecological literature, Coan et al. (2010) and Huber (2010) considered Perumytilus to be a junior synonym of Brachidontes. More recently, Coan \& Valentich Scott (2012: 119) used Perumytilus as a genus following its use by local authors. No new statement was included to support taxonomic change. Most of the primary characters considered to be of diagnostic significance are likely to show ecophenotypic variation. The taxonomic value of these features is open to discussion. Given that genus is a subjective category we prefer, for the time being, to keep both species studied here in the genus Brachidontes.

Olivier et al. (1966) reported only B. purpuratus in their ecological description of the rocky intertidal communities from Punta Pardelas,
Golfo Nuevo. Four decades later, Cuevas et al. (2006) indicated a mixture of both species at the same location. They concluded that the southern limit of $B$. rodriguezii in the southwestern Atlantic had expanded poleward to Caleta Olivia $\left(47^{\circ} 26^{\prime} \mathrm{S}\right)$ during the intervening period. Unfortunately, there are no voucher materials were deposited to confirm these records. Our examination of samples from museums, including those collected by Olivier (1957) (MLP 3720), showed that both species have been present in Golfo Nuevo since at least the early 20th century. Specimens of both mytilid species were collected at Puerto Madryn in 1915 (MACN-In 9174-6, 9174-36) and 1924 (MLP 2399). Torres \& Caille (2009) reported only $B$. rodriguezii from Puerto Madryn. In December 2009, we revisited their study sites and observed a mixture of the two species. We found no evidence of recent shifts in the range boundaries of Brachidontes spp. along the transition zone of the southwestern Atlantic, as suggested by previous authors. Kelaher et al. (2007) reported B. granulatus (Hanley, 1843) in the intertidal zone of Argentine Patagonia; apparently no voucher specimens from their study were kept (J. C. Castilla, personal communication). We did not find that species in our extensive survey ( $37^{\circ} \mathrm{S}$ to $\left.46^{\circ} \mathrm{S}\right)$. Brachidontes granulatus, a very distinctive species, is distributed along the central and northern coasts of Chile, and it is not present on the Atlantic coast of South America. Two species of Brachidontes are known to occur along the Argentine coast; both are ecologically significant ecosystem engineers in the intertidal zone of rocky shores and other consolidated substrata. The morphological shell characters highlighted in our study are sufficient to differentiate them, and should be used to that end in surveys of biodiversity and experimental studies. This is of particular relevance where their latitudinal ranges of distribution overlap.

\section{ACKNOWLEDGEMENTS}

E. Schwindt (CENPAT) helped with the collection of specimens from several localities of Patagonia. A. Mercado assisted with the illustrations. A. Tablado and A. Puig (MACN) facilitated use of their labs to $M$. A. to process material. Y. Finet and M. Huber (Geneve) kindly help our inquiries about the type specimens of M. purpurata. E. V. Coan and other unknown reviewer helped substantially to this work. We 
are also grateful to A. Tablado (MACN), C. Damborenea (MLP) and K. Way (NHMUK) for access to collections under their care. Part of this work was supported by CONICET (PIP 02126) and PICT 942 from Agencia Nacional de Promoción Científica y Tecnológica, Argentina; Participation of J. M. O. was supported by project PICT-2007-01839.

\section{LITERATURE CITED}

ADAMI, M. L., A. TABLADO \& J. J. LÓPEZ GAPPA, 2004, Spatial and temporal variability in intertidal assemblages dominated by the mussel Brachidontes rodriguezii (d'Orbigny, 1846). Hydrobiologia, 520: 49-59.

AGUIRRE, M. L., 1994, Type specimens of Quaternary marine bivalves from Argentina. Ameghiniana, 3: 347-374.

AGUIRRE, M. L., I. S. PEREZ \& Y. NEGRO SIRCH, 2006, Morphological variability of Brachidontes Swainson (Bivalvia, Mytilidae) in the marine Quaternary of Argentina (SW Atlantic). Palaeogeography, Palaeoclimatology, Palaeoecology, 239: 100-125.

BALECH, E. \& M. D. EHRLICH, 2008, Esquema biogeográfico del mar argentino. Revista de Investigación y Desarrollo Pesquero (Mar del Plata), 19: 45-75.

CASTELLANOS, Z. A., 1957, Los mitílidos Argentinos. Ministerio de Agricultura y Ganadería, Departamento de Investigaciones Pesqueras, $12 \mathrm{pp}$.

CASTELLANOS, Z. A. DE, 1970, Catálogo de los moluscos marinos bonaerenses. Anales de la Comisión de Investigación Científica. Gobernación de la Provincia de Buenos Aires, 8: 9-365.

COAN, E. V \& P. VALENTICH-SCOTT, 2012, Bivalve seashells of tropical west America. Marine bivalve mollusks from Baja California to northern Perú. Part 1. Santa Barbara Museum of Natural History, Santa Barbara, 596 pp.

COAN, E. V., P. VALENTICH-SCOTT \& F. R. BERNARD, 2000, Bivalve seashells of western North America: marine bivalve mollusks from Arctic Alaska to Baja California. Santa Barbara Museum of Natural History, Santa Barbara, $764 \mathrm{pp}$.

COX, L. R., et al., 1969, Systematic descriptions. Pp. N225-489, in: R. C. Moore, ed., Treatise on invertebrate paleontology. The University of Kansas \& the Geological Society of America, Boulder, Colorado.

CUEVAS, J. M., J. P. MARTIN \& R. BASTIDA, 2006 , Benthic community changes in a Patagonian intertidal: a forty years later comparison. Thalassas, 22: 29-37.

HUBER, M., 2010, Compendium of bivalves. A full-color guide to 3,300 of the world's marine bivalves. A status on Bivalvia after 250 years of research. ConchBooks, Hackenheim, 901 pp.
KELAHER, B P J C CASTILLA L PRADO, P YORK, E. SCHWINDT \& A. BORTOLUS, 2007, Spatial variation in molluscan assemblages from coralline turfs of Argentinean Patagonia. Journal of Molluscan Studies, 73: 139-146.

LAMARCK, J. B. P., 1819, Histoire naturelle des animaux sans vértebrés, Tome $6, \mathrm{Pt} 1$. Verdieve, Paris, $343 \mathrm{pp}$.

OLIVIER, S. R., I. K. PATERNOSTER DE \& R. BASTIDA, 1966, Estudios biocenóticos en las costas de Chubut (Argentina) I. Zonación biocenológica de Puerto Pardelas (Golfo Nuevo) Boletín Instituto de Biología Marina (Mar del Plata), 10: 5-71.

OLSSON, A. A., 1961, Mollusks of the tropical eastern Pacific. Panamic-Pacific Pelecypoda. Paleontological Research Institution, Ithaca, New York, 574 pp.

ORBIGNY, A. D. d', 1834-1847, Mollusques. In: C. P. Bertrand, ed., Voyage dans l'Amérique Méridionale (Le Bresil, La Republique Orientale de L'Uruguay, La Republique Argentine, La Patagonie, La Republique du Chili, La Republique de Bolivia, La Republique du Perou), éxecuté pendant les années 1826, 1827, 1828, 1829 1830, 1831, 1832 et 1833. Chez Ve, Levrault, Paris, vol. 5(3): xliii $+758,85$ pls. [in Atlas].

OSORIO, C., 2002, Moluscos marinos en Chile. Especies de importancia económica. Facultad de Ciencias, Universidad de Chile, $211 \mathrm{pp}$.

RAFINESQUE, C. S., 1815, Analyse de la natura ou tableau de l'univers et des corps organisés. Palermo, $223 \mathrm{pp}$.

RIOS, E. C., 1994, Seashells of Brazil, 2nd ed. Museu Oceanográfico da FURG, Rio Grande do Sul, $368 \mathrm{pp}$.

RIOS, E. C., 2009, Compendium of Brazilian sea shells. Evangraf, Rio Grande, R. S., 676 pp.

SEED, R., 1968, Factor influencing shell shape in the mussel Mytilus edulis. Journal of Marine Biological Association of the United Kingdom, 48: 561-584

SILLIMAN B. R., M. D. BERTNESS, A. H. ALTIERI, J. N. GRIFFIN, M. C. BAZTERRICA F. J. HIDALGO, C. M. CRAIN \& M. V. REYNA, 2011, Whole-community facilitation regulates biodiversity on Patagonian rocky shores. Plosone, 10: e24502.

SOOT-RYEN, T., 1955, A report on the family Mytilidae (Pelecypoda). Publications University Southern California, Allan Hancock Pacific Expeditions, 20: 1-175.

SWAINSON, W., 1840, A Treatise on malacology or shell and shell fish, Lardner's Cabinet Cyclopedia, $384 \mathrm{pp}$.

TORRES, A. \& G. CAILLE, 2009, Las comunidades del intermareal rocoso antes y después de la eliminación de un disturbio antropogénico: un caso de estudio en las costas de Puerto Madryn (Patagonia, Argentina). Revista de Biología Marina y Oceanografía (Chile), 44: 517-521.

Revised ms. accepted November 4, 2012 